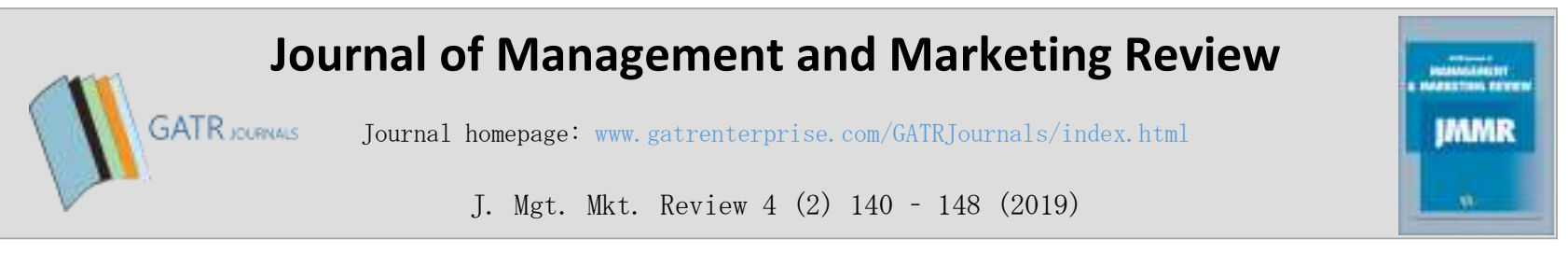

\title{
Consumer Attitude and Reaction towards Personalised Pricing in the E-Commerce Sector
}

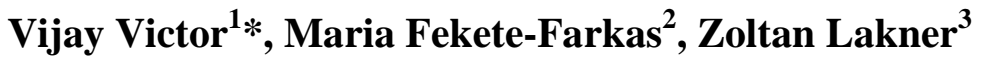 \\ ${ }^{1}$ Doctoral School of Management and Business Administration, Szent Istvan University, Godollo 2100, Hungary \\ ${ }^{2}$ Faculty of Economics and Social Sciences, Szent Istvan University, Godollo 2100, Hungary \\ ${ }^{3}$ Doctoral School of Management and Business Administration, Szent Istvan University, Godollo 2100, Hungary
}

\begin{abstract}
Objective - This study examines consumer attitudes and reactions towards personalised pricing strategies in a negative and positive hypothetical purchase context.

Methodology/Technique - The data was collected from 250 respondents from India through a set of two structured questionnaires, each one comprising either a positive or negative purchase scenario. Partial Least Square based Structural Equation Modelling (PLS SEM) was used to analyse the data.

Findings - The results of the study imply that the consumers are concerned about the usage of their personal data for price customisation which reduces their repurchase intentions and increases the reprisal intention. The results also depict that a loyal customer base reacts positively to some extent to the personalised pricing strategy.

Novelty -This study considers the impact of personalised pricing on the fair price perceptions, privacy concerns and customer loyalty in both positive and negative purchase contexts which is a novel in this research area.
\end{abstract}

Type of Paper: Empirical.

Keywords: Personalised Pricing; E-Commerce; Consumer Behaviour; Price Discrimination, PLS SEM.

Reference to this paper should be made as follows: Victor, V.; Farkas, M. F.; Lakner, Z. (2019). Consumer Attitude and Reaction towards Personalised Pricing in the E-Commerce Sector, J. Mgt. Mkt. Review, 4 (2): 140 - 148 https://doi.org/10.35609/jmmr.2019.4.2(6)

JEL Classification: D82, D90, D11

\section{Introduction}

With the big data technologies becoming so popular in recent years, the firms have more opportunities to gather information on consumer choices and preferences which help estimate their willingness to pay. This include both public and private information based on observed individual characteristics such as location, age, gender, employment and observed online behavioral patterns of consumers including search history, responsiveness to price offers etc. This has enabled firms to engage in more refined forms of price discrimination such as personalized pricing where the sellers grab a major share of the consumer surplus (Gehrig et. al., 2012).

\footnotetext{
* Paper Info: Revised: March 11, 2019

Accepted: June 19, 2019

* Corresponding author: Vijay Victor

E-mail: Victor.Vijay@phd.uni-szie.hu
}

Affiliation: Doctoral School of Management and Business Administration, Szent István University, Hungary 
The practice of customizing prices for individual customers or a group of customers who possess similar characteristics based on the information available about them is the most advanced form of pricing strategy identified in the E-Commerce segment. This axiomatically can be attributed to the practice of first degree price discrimination or the so called "perfect price discrimination" which enables the sellers to capture the entire consumer surplus (Armstrong, 2006). Yet, first degree price discrimination requires more precise information about the prospective customer and with the pace of current technological progress, it is not entirely unimaginable. However, despite the possibilities to estimate the willingness to pay of a consumer in real time, it is highly debatable whether the short term increase in revenue of a firm offsets the risk of losing a loyal customer base in the long run.

To be realistic, firms charge only a proportional share (not essentially the total value) of the consumer's willingness to pay. Since perfect information about consumers is rather difficult to gather, in personalized pricing, firms would be discriminating groups which show similar characteristics instead of individuals, which is an example for third degree price discrimination. In online markets where offers are highly tailored to individual needs, firms do customize both prices and products to consumers which may be considered as second degree price discrimination or versioning (Townley et. al., 2017). An OECD report published in 2018 defines personalized pricing as "any practice of price discriminating final consumers based on their personal characteristics and conduct, resulting in prices being set as an increasing function of consumers' willingness to pay" (OECD, 2018, p.9). Unlike the brick and mortar markets, the information gathered in the digital market about the consumers can help firms to estimate consumer's willingness to pay more accurately.

Many researchers identify customer relationship management as one of the key factors which determine the success of online retailers (Jap \& Ganesan, 2000; Palmatier et. al., 2006). The e-tailers have the ability to monitor consumer purchase patterns continuously and use the information acquired to serve the customers in a better way thereby improving their purchase satisfaction (Yoon et. al., 2008). However, in a world where data has become the new oil, individuals are increasingly cautious about sharing their personal data to third parties. Employing a hardly transparent pricing technique such as personalized pricing in this context should be given much thought and research. Notwithstanding the fact that personalized pricing is not widely practiced at present (OECD, 2018), it can be expected to be widespread in the near future. Given the benefits of the pricing strategy to the revenue management of firms, it is pivotal to determine how consumers react to this novel pricing strategy at an early stage of implementation which will help the firms to make adequate changes to their pricing strategies. This paper studies the attitudes and reactions of consumers towards the personalized pricing strategy in both negative and positive purchase contexts. The paper is structured as follows: Chapter 2 consists of a literature review followed by a discussion of the materials and methods employed and conclusions.

\section{Literature Review}

The practice of customizing prices for each individual customer based on the available information about the consumers is the most advanced form of pricing strategy identified in the E-Commerce. Very few studies are available in the field of personalized pricing as it is a relatively novel research area. This pricing strategy termed as personalized pricing is defined by the Office of Fair Trade, UK as “(...) the practice where businesses may use information that is observed, volunteered, inferred, or collected about individuals' conduct or characteristics, to set different prices to different consumers (whether on an individual or group basis), based on what the business thinks they are willing to pay." (OFT, 2013, pp.2).

The information asymmetry existing in the retail and online markets is one of the key factors which makes these price discrimination strategies practical. Goerge Akerlof coined the term 'Information Asymmetry' to describe a situation in which one party engaged in a transaction knows more information than the other (Akerlof, 1978). In a usual purchase scenario, the seller knows much more information about a product than the buyer. 


\subsection{Personalized Pricing with Information on Consumer Preferences}

The accuracy of data on consumer preferences and choices is the most critical factor which enables personalized price discrimination in digital markets. The data collected can be broadly categorized into three categories, shown in Table. 1

Table. 1 Categories of Personal Data Collected Online

\begin{tabular}{ccc}
\hline Volunteered Data & Observed Data & Inferred Data \\
\hline Name & IP Address & Income \\
\hline Phone Number & Operating System & Health Status \\
\hline Email Address & Past Purchases & Risk Profile \\
\hline Date of Birth & Website Visits & Responsiveness to Ads \\
\hline Address For Delivery & Speed of click through & Consumer Loyalty \\
\hline Responses to Survey & User's Location & Political Ideology \\
\hline Professional Occupation & Search History & Behavioural Bias \\
\hline Level of Education & "Likes" in Social Networks & Hobbies \\
\hline
\end{tabular}

Sources: OECD (2018), OFT (2013), EOP (2015)

One of the important questions to be addressed while employing personalized pricing is that how do consumer reactions change when suppliers have accurate and detailed information on consumer preferences. A relevant model in this regard is that of Esteves (2014). That model assumes that all suppliers in the market have sources to obtain private information on consumer preferences. However, the accuracy of the information collected may vary. At one end, they have completely useless information and on the other end the firm has accurate and perfectly usable information. The model results show that the more accurate the information collected is, the higher the opportunities to earn profits at the expense of consumers. However, competition between the firms becomes intense in this situation. Due to this extreme competition, aggregate consumer surplus increases and the situation becomes favorable to the consumers.

The personalization of prices may have an impact on consumers' fair price perceptions and purchase satisfaction which influences their repurchase intentions. The privacy concerns also pose a major problem in this regard. The significance of these factors in the E-Tail segment is explained below.

\subsection{Fair Price Perception}

Xia et al (2004) defines fair price perception as the assessment of a product's price by a consumer to determine whether it is reasonably justifiable. Assuming the buyer has perfect information regarding the prices and the utility gained from comparable products, he/she can decide a mix of products which can maximize his/her purchase satisfaction with given budget constraints (Monroe \& Xia, 2015). The more price conscious a buyer becomes, the more it shapes buyer perception about prices and the role price plays in buyer choice. Fair price perception of a consumer is formed through several reference points such as competitor prices, past prices, cost of manufacturing etc. (Monroe, 1973). Empirical studies have shown that if a consumer is not satisfied with the prices offered by a seller, they may show a negative behavior such as a tendency to avoid the seller in future purchases, taking revenge in the form of spreading negative news about the seller etc. (Xia et. al., 2004). By offering a price which a consumer perceives as fair will have a positive effect on his purchase satisfaction and repurchase intentions (Campbell, 2007; Roudposhti et. al., 2018).

\subsection{Purchase Satisfaction}

Purchase satisfaction is a key factor which determines the repurchase intentions of a consumer. Cronin et. al. (2000) outlines purchase satisfaction as the degree to which the customer thinks that the shopping 
experience induces positive feelings and signifies consumers' appraisal of the overall purchase experience as well as the purchase. Many studies have shown that systematic differences exist between online and offline shopping environments toward purchase satisfaction (Cao \& Li, 2015; Ansari et. al., 2008, Nisar \& Prabhakar, 2017). The internet customers have the option to control the purchase process and timing and expect a 24/7/365 service from the vendor. In simple words, the consumers have the option to shop and order products at their convenience and get them delivered at home at the click of a button. Even the buying process of an E-customer is much simpler than that of the traditional customer (Olah, 2018).

Previous researchers suggest that satisfaction with a purchase improves the confidence of buyers in a seller (Cronin et. al., 2000; Siau \& Shen, 2003). There are plenty of studies asserting the relationship between customer loyalty and purchase satisfaction (Hocutt, 1998; Hill, 2017). These studies show that consumers are satisfied when the sellers are able to cater to their level of expectations which in turn makes them loyal to the sellers. At the same time, when consumers are not satisfied, their loyalty towards the seller falls (Fedorko, 2018). Making the customers happy and satisfied will help in building a loyal customer base (Yang \& Peterson, 2004).

\subsection{Privacy Paradox}

With rapid advancements in technology, the business models in the E-Commerce segment have undergone many changes. Even digital footprints left by consumers in the web space are being used by firms to boost their revenue (Ashworth \& Free, 2006). Modern pricing strategies such as dynamic pricing and personalized pricing which actively involve the use of consumer data for product and price customization are good examples for these data driven business strategies. In the current scenario, data disclosure is inevitable at least to some extent in the online shopping context (Maury \& Kleiner, 2002). Although consumers are willing to share their personal information for perceived benefits, the non-transparent and sophisticated methods used in collecting their personal information have made them dubious about the usage of it by the sellers and its potential advantages and disadvantages (Palmer, 2005, Dienlin \& Trepte, 2015). Researchers have attempted to term this confusing state as 'Privacy Paradox' (Brown, 2004; Norberg et. al., 2007) which in simple words refers to the dichotomy between the intentions of people towards the disclosure of personal data and their actual behavior (Kokolakis, 2017). This term stems from the idea that despite being highly concerned about privacy, individuals are willing to trade their personal information for perceived benefits.

\section{Materials and Methods}

The study was conducted among the internet savvy millennials in India. Two set of questionnaires which exposed the respondents to either a positive or negative hypothetical purchase scenarios were administered to capture the response of consumers in a personalized pricing context. The scenario used in the research was adapted from Dai (2010) and modified to fit the needs of the present study. The reaction of the respondents was elicited using 5 point Likert scale based questions. A total of 250 responses were finalized for the PLS SEM analysis; 125 responses per questionnaire. The respondents were randomly assigned to either of the questionnaires. In the purchase scenarios developed, the magnitude of the price difference is set as a major factor forming the fair price perceptions of the consumers. The purchase scenarios also comprised information which makes the respondents aware of the application of personalized pricing in real time and the potential privacy concerns. The scale to test customer loyalty was given in the first part of the questionnaire prior to exposing the respondents to the purchase scenario. This was done with the intention to obtain the real attitudes of the consumers towards the seller and to obtain unbiased results as an independent variable. The research model framed was finally tested individually with both sets of data collected using the two different questionnaires. 


\subsection{Assessment of the Measurement Model}

The measurement model was assessed by testing for construct validity, convergent validity and discriminant validity. Composite Reliability, Average Variance Extracted (AVE) and Factor Loadings were used for the assessment as recommended by Hair et. al. (2016). The results for both positive purchase scenario and negative purchase scenario are shown in Table 2.

Table. 2 Results of the Measurement Model

\begin{tabular}{|c|c|c|c|c|c|c|c|c|c|c|}
\hline & \multicolumn{2}{|c|}{$\begin{array}{c}\text { Cronbach's } \\
\text { Alpha }\end{array}$} & \multicolumn{2}{|c|}{ Rho_A } & \multicolumn{2}{c|}{$\begin{array}{c}\text { Composite } \\
\text { Reliability }\end{array}$} & \multicolumn{2}{c|}{$\begin{array}{c}\text { Average } \\
\text { Variance } \\
\text { Extracted }\end{array}$} & \multicolumn{2}{c|}{$\begin{array}{c}\text { Factor } \\
\text { Loadings }\end{array}$} \\
\cline { 2 - 10 } & Pos & Neg & Pos & Neg & Pos & Neg & Pos & Neg & Pos & Neg \\
\hline $\begin{array}{c}\text { Customer } \\
\text { Loyalty }\end{array}$ & 0.919 & 0.932 & 0.927 & 0.936 & 0.935 & 0.945 & 0.673 & 0.710 & $0.77-0.89$ & $0.85-0.92$ \\
\hline $\begin{array}{c}\text { Fair Price } \\
\text { Perception }\end{array}$ & 0.906 & 0.886 & 0.919 & 0.888 & 0.93 & 0.930 & 0.727 & 0.815 & $0.79-0.86$ & $0.79-0.88$ \\
\hline $\begin{array}{c}\text { Privacy } \\
\text { Concerns }\end{array}$ & 0.801 & 0.768 & 0.808 & 0.815 & 0.862 & 0.838 & 0.557 & 0.514 & $0.62-0.85$ & $0.59-0.84$ \\
\hline $\begin{array}{c}\text { Purchase } \\
\text { Satisfaction }\end{array}$ & 0.937 & 0.929 & 0.94 & 0.932 & 0.95 & 0.945 & 0.732 & 0.740 & $0.68-0.92$ & $0.59-0.84$ \\
\hline $\begin{array}{c}\text { Reprisal } \\
\text { Intentions }\end{array}$ & 0.819 & 0.805 & 0.835 & 0.855 & 0.866 & 0.864 & 0.566 & 0.563 & $0.68-0.83$ & $0.83-0.91$ \\
\hline $\begin{array}{c}\text { Repurchase } \\
\text { Intentions }\end{array}$ & 0.87 & 0.865 & 0.87 & 0.876 & 0.92 & 0.909 & 0.793 & 0.716 & $0.88-0.89$ & $0.70-0.85$ \\
\hline
\end{tabular}

Notes - Pos: Positive Purchase Scenario, Neg: Negative Purchase Scenario

The results in Table 2 show that both models satisfy the convergent and construct validity criteria. The composite reliability values are above 0.80 for both models and the AVEs are above 0.50 which explains that the constructs are able to expose more than $50 \%$ of the variance in the indicators. Items having factor loadings in the range of $0.40-0.70$ can be retained in the model if it positively affects the composite reliability (Hair et. al., 2016). Some items with factor loadings above 0.50 were retained after examining their effect on the composite reliability. Discriminant validity was tested using the Fornell-Larcker technique. The measurement model satisfies the discriminant validity criterion if the square root values of each construct more than that of the correlation between the items and other items (Fornell \& Larcker, 1981). Both models satisfy the discriminant validity criterion.

\subsection{Assessment of the Structural Model}

Figure 1 depicts the framework used for the study. The research framework was tested using the data from both purchase scenarios. Items PS5, PS7 and RI4 were removed due to low factor loadings. Item PC5 probes answers to the questions regarding the availability of an opt-out choice in sharing customers' personal data for price customization. The majority of the respondents in both purchase scenarios agreed in favour of an opt-out choice and the factor loading for that item is 0.81 . 


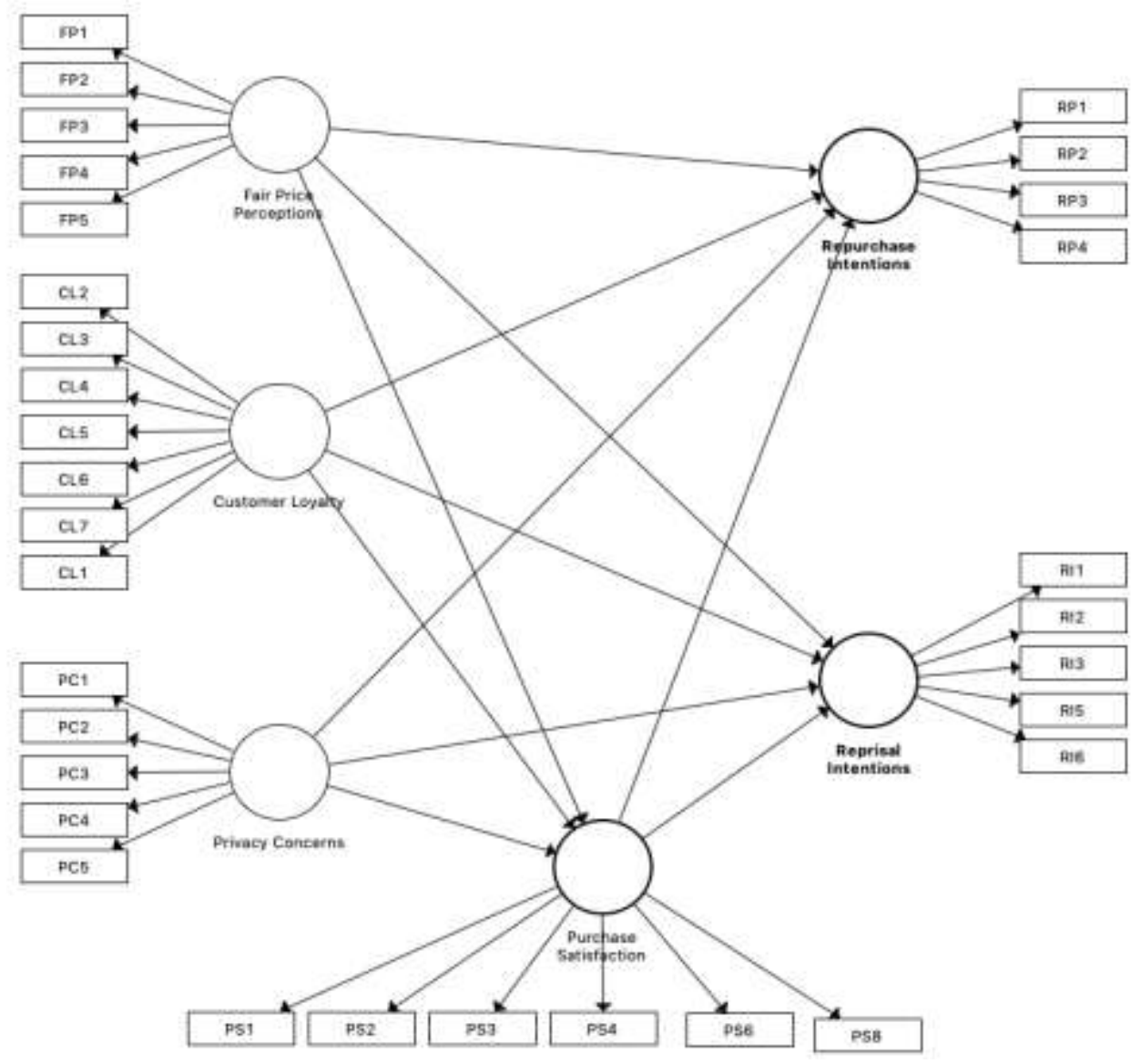

Figure 1. Structural Model

The R-square values for purchase satisfaction in positive and negative purchase scenarios were 0.78 and 0.71 respectively. For repurchase intentions the R-square values were 0.38 and 0.44 , for reprisal intentions they were 0.28 and 0.26 .

Table. 3 Path Analysis

\begin{tabular}{|c|c|c|c|c|c|c|}
\hline & \multicolumn{5}{c|}{ Pegative Purchase Scenario } \\
\hline & $\begin{array}{c}\text { Original } \\
\text { Sample (O) }\end{array}$ & $\begin{array}{c}\text { T Statistics } \\
(\mid \text { O/STDEV })\end{array}$ & $\begin{array}{c}\mathrm{p} \\
\text { Values }\end{array}$ & $\begin{array}{c}\text { Original } \\
\text { Sample }(\mathrm{O})\end{array}$ & $\begin{array}{c}\text { T Statistics } \\
(\mid \mathrm{O} / \text { STDEV })\end{array}$ & $\begin{array}{c}\mathrm{p} \\
\text { Values }\end{array}$ \\
\hline CL -> PS & 0.205 & 4.109 & $\mathbf{0 . 0 0 0}$ & 0.261 & 4.142 & $\mathbf{0 . 0 0 0}$ \\
\hline CL -> RI & 0.007 & 0.034 & 0.973 & -0.172 & 1.432 & 0.152 \\
\hline CL -> RPI & 0.443 & 4.504 & $\mathbf{0 . 0 0 0}$ & 0.27 & 2.494 & $\mathbf{0 . 0 1 3}$ \\
\hline FPP -> PS & 0.748 & 18.038 & $\mathbf{0 . 0 0 0}$ & 0.163 & 2.826 & $\mathbf{0 . 0 0 0}$ \\
\hline FPP -> RI & 0.278 & 1.101 & 0.272 & 0.691 & 15.315 & 0.665 \\
\hline FPP -> RPI & -0.102 & 0.578 & 0.564 & -0.084 & 0.444 & 0.657 \\
\hline PC -> PS & -0.027 & 0.453 & 0.651 & -0.103 & 1.901 & 0.057 \\
\hline PC -> RI & 0.292 & 1.832 & 0.048 & 0.231 & 2.369 & 0.018 \\
\hline PC -> RPI & -0.186 & 2.173 & 0.003 & 0.007 & 0.103 & 0.918 \\
\hline PS -> RI & -0.407 & 1.623 & 0.105 & -0.262 & 1.446 & 0.148 \\
\hline PS -> RPI & 0.307 & 1.692 & $\mathbf{0 . 0 9 1}$ & 0.594 & 4.141 & $\mathbf{0 . 0 0 0}$ \\
\hline
\end{tabular}


In both the positive and negative purchase scenarios, the fair price perception of consumers has a very significant and positive influence on their purchase satisfaction. This finding concurs with the results of a previous study by Dai (2010) which analysed consumers' reaction towards dynamic pricing. In the Negative Purchase Scenario, the purchase satisfaction of consumers has a positive impact on their repurchase intentions which hints that by making customers satisfied with their purchases, sellers can retain them. However, it is not the same in the Positive Purchase Scenario where the effect is not significant and it is customer loyalty which has a positive influence on the repurchase intentions.

The reason for this result might be that the consumers in a positive purchase scenario are leveraging the benefits of personalised pricing and the extent of personal gain is the factor which drives repurchase intentions rather than the total purchase satisfaction. The construct of privacy concerns is positively associated with the reprisal intentions in both scenarios which implies that the increased risks associated with sharing personal data and privacy concerns can induce the consumers to move toward reprisal intentions which include spreading negative news about the seller by word of mouth or on social media etc. In the Positive Purchase Scenario, privacy concerns is negatively related to the repurchase intentions displaying consumers' fear of risking their personal information for personalised price and product customisations despite the benefits.

Table 4. Mediation Effects

\begin{tabular}{|c|c|c|}
\hline \multicolumn{2}{|c|}{ Negative Purchase Scenario } \\
\hline Indirect Effects & $\begin{array}{c}\text { Original } \\
\text { Sample }\end{array}$ & P Values \\
\hline Customer Loyalty -> Purchase Satisfaction -> Repurchase Intentions & 0.155 & $\mathbf{0 . 0 0 2}$ \\
\hline Fair Price Perceptions -> Purchase Satisfaction -> Repurchase Intentions & 0.41 & $\mathbf{0 . 0 0}$ \\
\hline
\end{tabular}

Note - Showing only significant indirect effects.

In the Negative Purchase Scenario, purchase satisfaction plays a positive mediating role in the relationship between customer loyalty and repurchase intentions. The fair price perception of consumers has an indirect effect on the repurchase intentions which is mediated by purchase satisfaction. There were no significant mediation effects in the positive purchase scenario.

\section{Conclusions}

The study concludes with a note that modern consumers are sensitive towards the personalized pricing strategy which involves tailoring of prices to each individual or group of individuals. Regardless of the positive or negative purchase scenarios to which the consumers were exposed, the study shows an increasing resentment in the use of their personal data for customizing individual prices and product recommendations which also lead to many reprisal activities including the display of their dissatisfaction against the seller on social media and by word of mouth. Customer loyalty is an important factor which plays a major role in determining the repurchase intentions and purchase satisfaction.

From the study it can be seen that a loyal customer base reacts positively to personalized pricing strategies to some extent as they believe that the pricing strategy has benefits for them as well. Another significant result is that the majority of the respondents opined that they would be happy if there was an opt-out choice with regard to sharing their personal data for personlizing prices and product offers. This implies that having an impression that personalized pricing is a choice induces a sense of inclusiveness in the pricing process among consumers which further increases their trust in the seller.

The purchase satisfaction of consumers play a mediating role in the consumers' repurchase, reprisal and strategic behavioural intentions. Purchase satisfaction is mainly associated with the fair price perceptions of consumers. Hence, offering a price which consumers perceive as fair will improve their pruchase satisfaction 
and will have a subsequent positive effect on their post purchase intentions. The results of this study are best applicable to consumers in the Indian E- Tail segment but also to other groups of consumers with similar traits. Future studies in this direction should consider including more constructs which influence consumer behavior in a personalized pricing context with a larger sample size from across the world.

\section{References}

Akerlof, G. A. (1978). The market for "lemons": Quality uncertainty and the market mechanism. In Uncertainty in economics (pp. 235-251). Academic Press https://www.sciencedirect.com/science/article/pii/B978012214850750022X Ansari, A., Mela, C. F., \& Neslin, S. A. (2008). Customer channel migration. Journal of Marketing Research, 45(1), 6076 https://journals.sagepub.com/doi/abs/10.1509/jmkr.45.1.060

Armstrong, M. (2006). Recent developments in the economics of price discrimination. Cambridge University Press http://discovery.ucl.ac.uk/14558/

Ashworth, L. and Free, C. (2006). Marketing Dataveillance and Digital Privacy: Using Theories of Justice to Understand Consumers' Online Privacy Concerns. Journal of Business Ethics, 67(2), 107-123.

Brown, M., \& Muchira, R. (2004). Investigating the relationship between Internet privacy concerns and online purchase behavior. Journal of Electronic Commerce Research, 5(1), 62-70 https://web.csulb.edu/journals/jecr/issues/20041/Paper6.pdf

Campbell, S. W. (2007). Perceptions of Mobile Phone Use in Public Settings: A Cross-cultural Comparison. International Journal of Communication, 1(1), 20.

Cao, L. and Li, L. (2015). The Impact of Cross-channel Integration on Retailers' Sales Growth. Journal of Retailing, 91(2), 198-216.

Cronin Jr, J. J., Brady, M. K. and Hult, G. T. M. (2000). Assessing the Effects of Quality, Value, and Customer Satisfaction on Consumer Behavioral Intentions in Service Environments. Journal of Retailing, 76(2), 193-218.

Dai, B. (2010). The impact of perceived price fairness of dynamic pricing on customer satisfaction and behavioral intentions: The moderating role of customer loyalty (Doctoral dissertation) http://etd.auburn.edu/handle/10415/2217

Dienlin, T. and Trepte, S. (2015). Is the Privacy Paradox a Relic of the Past? An In-depth Analysis of Privacy Attitudes and Privacy Behaviors. European Journal of Social Psychology, 45(3), 285-297.

EOP (2015), "Big Data and Differential Pricing", Executive Office of the President, United States, https://obamawhitehouse.archives.gov/sites/default/files/whitehouse_files/docs/Big_Data_Report_Nonembargo_v2.pdf

Esteves, R. B. (2014). Price Discrimination with Private and Imperfect Information. The Scandinavian Journal of Economics, 116(3), 766-796.

Fedorko, R., Fedorko, I., Riana, I. G., Rigelsky, M., Olearova, M. and Obsatnikova, K. (2018). The Impact of Selected Elements of E-commerce To E-shop Recommendation. Polish Journal of Management Studies, 18.

Fornell, C. and Larcker, D. F. (1981). Structural Equation Models with Unobservable Variables and Measurement Error: Algebra and Statistics.

Gehrig, T., Shy, O. and Stenbacka, R. (2012). A Welfare Evaluation of History-based Price Discrimination. Journal of Industry, Competition and Trade, 12(4), 373-393.

Hair Jr, J. F., Hult, G. T. M., Ringle, C. and Sarstedt, M. (2016). A Primer on Partial Least Squares Structural Equation Modelling (PLS-SEM). Sage Publications.

Hill, N. and Alexander, J. (2017). The Handbook of Customer Satisfaction and Loyalty Measurement. Routledge.

Hocutt, M. A. (1998). Relationship Dissolution Model: Antecedents of Relationship Commitment and the Likelihood of Dissolving a Relationship. International Journal of Service Industry Management, 9(2), 189-200.

Jap, S. D. and Ganesan, S. (2000). Control Mechanisms and Relationship Life Cycle: Implications for Safeguarding Specific Investments and Developing Commitment. Journal of Marketing Research, 37, 227-245.

Kokolakis, S. (2017). Privacy Attitudes and Privacy Behaviour: A Review of Current Research on the Privacy Paradox Phenomenon. Computers and Security, 64, 122-134.

Maury, M. D. and Kleiner, D. S. (2002). E-commerce, Ethical Commerce? Journal of Business Ethics, 36(1-2), $21-31$. Monroe, K., B. (1973) Buyers' Subjective Perceptions of Price. Journal of Marketing Research 10(1) 70-80.

Monroe, K. B. and Xia, L. (2015). The Price is Unfair. Does Marketing Need Reform, 158-165.

Nisar, T. M. and Prabhakar, G. (2017). What Factors Determine E-satisfaction and Consumer Spending in E-commerce Retailing? Journal of Retailing and Consumer Services, 39, 135-144. 
Norberg, P. A., Horne, D. R. and Horne, D. A. (2007). The Privacy Paradox: Personal Information Disclosure Intentions versus Behaviors. Journal of Consumer Affairs, 41(1), 100-126.

OECD (2018). Personalised Pricing in the Digital http://www.oecd.org/officialdocuments/publicdisplaydocumentpdf/?cote=DAF/COMP(2018)13\&docLanguage=En. Retrieved on April 15, 2019.

OFT (2013), Personalised Pricing - Increasing Transparency to Improve Trust, Office of Fair Trading, https://webarchive.nationalarchives.gov.uk/20140402142426/http:/www.oft.gov.uk/shared_oft_/marketswork/personalised-pricing/oft1489.pdf.

Oláh, J., Kitukutha, N., Haddad, H., Pakurár, M., Máté, D. and Popp, J. (2018). Achieving Sustainable E-Commerce in Environmental, Social and Economic Dimensions by Taking Possible Trade-Offs. Sustainability, 11(1), 1-22.

Palmatier, R. W., Dant, R. P., Grewal, D. and Evans, K. R. (2006). Factors Influencing the Effectiveness of Relationship Marketing: A Meta-analysis. Journal of Marketing, 70, 136-153.

Palmer, D. E. (2005). Pop-ups, Cookies, and Spam: Toward a Deeper Analysis of the Ethical Significance of Internet Marketing Practices. Journal of Business Ethics, 58(1-3), 271-280.

Roudposhti, V. M., Nilashi, M., Mardani, A., Streimikiene, D., Samad, S. and Ibrahim, O. (2018). A New Model for Customer Purchase Intention in E-commerce Recommendation Agents. Journal of International Studies Vol, 11(4).

Siau, K. and Shen, Z. (2003). Mobile Communications and Mobile Services. International Journal of Mobile Communications, 1(1-2), 3-14.

Townley, C. P., Yeung, K. and Morrison, E. (2017). Big Data and Personalised Price Discrimination in EU Competition Law.

Xia, L., Monroe, K. B. and Cox, J. L. (2004). The Price is Unfair! A Conceptual Framework of Price Fairness Perceptions. Journal of Marketing, 68(October), 1-15.

Yang, Z. and Peterson, R. T. (2004). Customer Perceived Value, Satisfaction, and Loyalty: The Role of Switching Costs. Psychology and Marketing, 21(10), 799-822.

Yoon, D., Choi, S. M. and Sohn, D. (2008). Building Customer Relationships in an Electronic Age: The Role of Interactivity of Ecommerce Web Sites. Psychology and Marketing, 25(7), 602-618. 